\title{
PANDANGAN UMAT BUDDHA TERHADAP HUKUM DAN ADMINISTRASI KEPENDUDUKAN DI DESA MARGOREJO, TEGINENENG, KABUPATEN PESAWARAN, LAMPUNG
}

\author{
Warsito \\ Sekolah Tinggi Agama Buddha Negeri Sriwijaya, Tangerang, Banten \\ warsitosuranata79@gmail.com
}

\begin{abstract}
ABSTRAK
Kata Kunci : Pandangan, Umat Buddha, Hukum, Administrasi Kependudukan.

Warsito, Pandangan Umat Buddha Terhadap Hukum dan Administrasi Kependudukan di Desa Margorejo, Tegineneng, Kabupaten Pesawaran, Lampung.

Dalam menyikapi berbagai masalah yang berhubungan dengan hukum dan administrasi kependudukan pemerintah berusaha memperoleh data tentang kependudukan di Indonesia yang akurat untuk mampu membuat pemetaan yang tepat guna untuk menanggulangi masalah kependudukan baik tingkat lokal dan nasional. Pendaftaran Penduduk adalah pencatatan biodata penduduk, pencatatan atas pelaporan peristiwa Kependudukan dan Pendataan Penduduk Serta Penerbitan Dokumen Kependudukan berupa kartu identitas atau Surat Keterangan Kependudukan. Pengelolaan pendaftaran penduduk merupakan tanggung jawab pemerintah kota/kabupaten, dimana dalam pelaksanaan diawali dari desa/kelurahan selaku ujung tombak pendaftaran penduduk,sehingga setiap warga terdaftar secara administrasi dan sesuai dengan Undang-undang Nomor 24 Tahun 2013 tentang Administrasi kependudukan. Masalah yang muncul dalam masyarakat desa adalah kurang kepedulian terhadap kewajiban sebagai warga masyarakat berkaitan dengan hukum dan administrasi kependudukan. Untuk itu peran pemerintah desa dalam hal ini kepala Desa bekerjasama dengan sekretaris desa yang dikoordinir oleh kepala dusun dan Ketua RT mutlak dioptimalkan.
\end{abstract}

Penelitian ini memiliki tujuan untuk agar pelayanan Hukum dan Administrasi Kependudukan bagi umat Buddha di Desa Margorejo, Pesawaran, Lampung berjalan dengan maksimal sehingga hambatan-hambatan yang terjadi dapat diatasi dengan baik, melalui kerjasama Ketua Vihara, umat Buddha dan pejabat pemerintah desa. Pendekatan penelitian menggunakan metode kualitatif dengan subjek penelitian Ketua Vihara, Umat Buddha dan Perwakilan dari Kepala Dusun. Teknik Pengumpulan Data yang dilakukan dengan Observasi, Wawancara dan Dokumentasi. Teknik analisis data yang digunakan adalah model Miles and Huberman yaitu pengumpulan data, reduksi data, penyajian dan penarikan kesimpulan.

Berdasarkan hasil penelitian dan pembahasan maka dapat disimpulkan bahwa Pelayanan Hukum dan Administrasi Kependudukan bagi umat Buddha berjalan dengan baik walaupun terdapat kekurangan yakni kurang pedulinya umat Buddha 
terhadap kewajiban sebagai warga masyarakat dalam hal pelaksanaan hukum dan administrasi kependudukan di desa. Hambatan yang terjadi adalah selain kurang pedulinya umat Buddha, dari pihak pemerintah desa kurang mengadakan sosialisasi dan tidak ada penjelasan yang memadai mengenai program pelayanan hukum dan kependudukan.

\section{ABSTRACT}

Keywords : View, Buddhist, Law and Population Administration.

Warsito, Buddhist View of Law and Population Administration in Margorejo Village,Tegineneng, Pesawaran, District Lampung

In addressing various issues relating to the law and population administration the government seeks to obtain accurate data on population in Indonesia to be able to make appropriate mapping to address demographic problems both locally and nationally. Population Registration is the recording of population biodata, recording of the reporting of the event Population and Population Data Collection and Publication of Population Document in the form of identity card or Demographic Identification Letter. The management of population registration is the responsibility of the city / district government, where in the implementation begins from the village as the spearhead of the registration of the population, so that every citizen is registered administratively and in accordance with Act Number 24 of 2013 on Population Administration. The problem that arises in the village community is the lack of awareness of the obligations as citizens in relation to law and population administration. Therefore, the role of village government in this case the village head in cooperation with the village secretary coordinated by the head of the hamlet and the head of RT is absolutely optimized.

This research has a purpose to make the service of Law and Population Administration for Buddhist in Margorejo Village, Pesawaran, Lampung to run maximally so that the obstacles can be overcome well, through cooperation of Chairman of Vihara, Buddhist and village government officials. The research approach uses qualitative method with research subject of Chairman of Vihara, Buddhist and Representative of Head of Dusun. Data Collection Techniques conducted with Observation, Interview and Documentation. Data analysis technique used is Miles and Huberman model that is data collection, data reduction, presentation and conclusion.

Based on the results of research and discussion it can be concluded that the Legal Services and Population Administration for Buddhists run well despite the shortcomings of the lack of care of Buddhists to the obligation as citizens in the implementation of law and population administration in the village. The obstacles that occur are in addition to the lack of care of Buddhists, from the village government does not hold socialization and there is no adequate explanation about the program of legal services and population. 


\section{Pendahuluan}

Negara kesatuan Republik Indonesia berdasarkan Pancasila dan Undangundang Dasar Republik Indonesia tahun 1945 pada hakekatnya berkewajiban untuk memberikan perlindungan dan pengakuan terhadap penentuan status pribadi dan status hukum setiap peristiwa kependudukan dan peristiwa penting yang dialami oleh penduduk yang berada didalam atau diluar wilayah Negara Kesatuam Republik Indonesia. Untuk menyikapi berbagai masalah yang berhubungan dengan kependudukan pemerintah berusaha memperoleh data tentang kependudukan di indonesia yang akurat untuk mampu membuat pemetaan yang tepat guna untuk menanggulangi masalah kependudukan baik tingkat lokal dan nasional.Pendaftaran Penduduk adalah pencatatn biodata penduduk, pencatatan atas pelaporan peristiwa Kependudukan dan pendataan Penduduk Rentan Administrasi Kependudukan Serta Penerbitan Dokumen Kependudukan berupa kartu identitas atau Surat Keterangan Kependudukan. Pengelolaan pendaftaran penduduk merupakan tanggung jawab pemerintah kota/kabupaten, dimana dalam

pelaksanaan diawali dari desa/kelurahan selaku ujung tombak pendaftaran penduduk,sehingga setiap warga terdaftar secara administrasi dan sesuai dengan Undang-undang No 24 Tahun 2013 tentang Administrasi kependudukan.

Peristiwa kependudukan yang di maksud antara lain adalah perubahan alamat, pindah datang untuk menetap, tinggal terbatas, serta perubahan status orang asing tinggal terbatas menjadi tinggal tetap dan peristiwa penting antara lain kelahiran, lahir mati, kematian, perkawinan, perceraian, termasuk pengangkatan, pengakuan, dan pengesahan anak, serta perubahan status kewarganegaraan, ganti nama dan 
peristiwa penting lainnya yang dialami oleh seseorang merupakan kejadian yang harus dilaporkan karena membawa implikasi perubahan data identitas atau surat keterangan kependudukan. Untuk itu, setiap peristiwa penting memerlukan bukti yang sah untuk dilakukan pengadministrasian dan pencatan sesuai dengan ketentuan undang undang (Burhanudin, 2008) Pencatatan dan pengolahan data penduduk merupakan tanggung jawabpemerintah kabupaten/kota, dimana pelaksanaannya diawali dari kelurahan selaku ujung tombak pendaftaran penduduk. Pelayanan tersebut perlu dilakukan dengan cepat dan tepat untuk mendapatkan suatu informasi. Tetapi pada kenyataannya, pengolahan data pada kelurahan atau desa masih dilakukan dalam bentuk pembukuan atau arsip-arsip, sehingga seringkali terjadi kesalahan bahkan ada arsip data yang hilang atau rusak karena terlalu banyaknya arsip yang ada. Pada aktifitas pelayanan kependudukan, warga diharuskan mengurus surat surat permohonan yang diinginkan pada kantor desa/ kelurahan dengan mengikuti sejumlah prosedur prosedur yang berlaku sehingga dalam pembuatan surat surat tertentu akan memakan waktu dan tenaga yang cukup lama.

Sistem Informasi Administrasi Kependudukan (SIAK), SIAK adalah Suatu sistem Informasi yang disusun berdasarkan prosedur-prosedur dan berbasis teknologi informasi dan komunikasi yang bertujuan untuk menata sistem administrasi kependudukan di indonesia, sistem ini meliputi pendataan penduduk dan catatan sipil. Keberadaan sistem administrasi kependudukan akan menghasilkan data kependudukan yang akurat, baik dari segi jumlah penduduk, tingkat ekonomi, pendidikan, dan lain-lain sehingga dengan data yang akurat 
tesebut berguna untuk implementasi kebijakan atau program pemerintahan lainnya. Dokumen Kependudukan adalah dokumen resmi yang di terbitkan oleh Dinas yang mempunyai kekuatan hukum sebagai alat bukti autentik yang dihasilkan dari pelayanan pendaftaran penduduk dan pencatatan sipil. Administrasi dalam arti luas adalah segenap proses kegiatan untuk mencapai tujuan, sedangkan administrasi dalam arti yang sempit adalah segenap proses pelayanan untuk mencapai tujuan. Administrasi kependudukan adalah rangkaian kegiatan dan penataan dan penertiban dalam penerbitan dokumen dan data kependudukan melalui pendaftaran penduduk, pencatatan sipil, pengelolaan informasi Administrasi kependudukan serta pendayagunaan yang hasilnya untuk pelayanan publik dan pembangunan sektor lain. Penyelenggara yang mengelola adalah pemerintah, pemerintah provinsi dan pemerintah kabupaten/kota yang bertanggung jawab dan berwenang dalam urusan administrasi kependudukan.

Pelaksanaan pelayanan pencatatan sipil meliputi:

1. Pencatatan Peristiwa Kelahiran

2. Pencatatan Peristiwa Kematian

3. Pelayanan pembuatan kartu tanda penduduk

4. Pelayanan pembuatan Kartu Keluarga (KK)

5. Lahir mati

6. Pencatatan Perkawinan.

7. Pencatatan Perceraian

8. Pengakuan anak

9. Pengesahan anak 
10. Pengangkatan anak

11. Perubahan nama

12. Perubahan status kewarganegaraan

13. Pembatalan perkawinan

14. Pembatalan perceraian

Setiap Peristiwa Kependudukan memerlukan bukti yang sah untuk dilakukan pengadministrasian dan pencatatan sesuai dengan ketentuan undang-undang. Sesuai dengan perubahan dan perkembangan yang terjadi dalam masyarakat Indonesia maka masyarakat Indonesia sadar bahwa seseorang perlu memiliki bukti tertulis dalam menentukan status seseorang atas kejadian-kejadian atau peristiwa-peristiwa, misalnya: perkawinan, kelahiran kematian, pengakuan anak, pengesahan anak, perceraian, kematian maupun pergantian nama, sedangkan untuk memiliki status tersebut, maka orang tersebut harus mendaftarkan peristiwa atau kejadian itu pada Lembaga Catatan Sipil, dengan demikian orang tersebut akan memperoleh bukti tertulis yang berupa Akta Catatan Sipil. KTP (Kartu Tanda Penduduk) adalah indentitas resmi penduduk sebagai bukti diri yang di terbikan oleh instansi pelaksana dan berlaku di seluruh wilayah republik Indonesia.

Di dalam Pasal 7 Undang-undang nomor 24 Tahun 2013 tentang perubahan atas undang-undang nomor 23 Tahun 2006 tentang administrasi kependudukan adalah: 
1) Pemerintah kabupaten/kota berkewajiban dan bertanggung jawab menyelenggarakan urusan Administrasi Kependudukan, yang dilakukan oleh bupati/walikota dengan kewenangan meliputi :

a. Koordinasi penyelenggaraan Administrasi Kependudukan;

b. Pembentukan Instansi Pelaksana yang tugas dan fungsinya di bidang Administrasi Kependudukan.

c. pengaturan teknis penyelenggaraan Administrasi Kependudukan sesuai dengan ketentuan Peraturan Perundang-undangan.

d. Pembinaan dan sosialisasi penyelenggaraan Administrasi Kependudukan;

e. Pelaksanaan kegiatan pelayanan masyarakat di bidang Administrasi Kependudukan.

f. Penugasan kepada desa untuk menyelenggarakan sebagian urusan Administrasi Kependudukan berdasarkan asas tugas pembantuan.

g. Penyajian Data Kependudukan berskala kabupaten/kota berasal dari Data Kependudukan yang telah dikonsolidasikan dan dibersihkan oleh Kementerian yang bertanggung jawab dalam urusan pemerintahan dalam negeri.

h. Koordinasi pengawasan atas penyelenggaraan Administrasi Kependudukan.

2) Ketentuan sebagaimana dimaksud pada ayat (1) di Provinsi Daerah Khusus Ibukota Jakarta dilaksanakan oleh Pemerintah Provinsi Daerah Khusus Ibukota Jakarta. Bahwa pelayanan KTP di Kabupaten Malang dilakukan oleh kedua lembaga yaitu Dinas Kependudukan Pencatatan Sipil dan Kecamatan,berdasarkan pasal 7 ayat (1) huruf. 
Desa Margorejo yang terletak di Kecamatan Tegineneng Kabupaten Pesawaran Lampung yang pada mulanya dibawah pemerintahan Kecamatan Natar Kabupaten Lampung Selatan, namun semenjak tahun 2008 dalam rangka meningkatkan otonomi daerah seiring dengan terjadinya pemekaran wilayah Kabupaten, sehingga kini berada dibawah pemerintahan Kabupaten Pesawaran. Luas desa Margorejo adalah 1.029 ha/m2 yang terdiri dari wilayah pemukiman, persawahan, perkebunan, dan prasaranan lainnya. Sebelah Utara berbatasan dengan wilayah desa Gerning kecamatan Tegineneng, sebelah Selatan berbatasan dengan wilayah desa Watu Agung Kecamatan Kalirejo Kabupaten Lampung Tengah, sebelah Timur berbatasan dengan wilayah desa Sinar Jati Kecamatan Tegineneng, dan sebelah Barat berbatasan dengan wilayah desa Bangun Rejo Kecamatan Bangun Rejo Kabupaten Lampung Tengah. Sumber daya alam adalah sesuatu yang dapat dimanfaatkan untuk berbagai kepentingan dan kebutuhan hidup manusia agar dapat hidup lebih sejahtera, dan terdapat di sekitar alam lingkungan hidup kita. Sumber daya alam bisa terdapat di mana saja seperti di dalam tanah, air, permukaan tanah, udara, dan lain sebagainya. Usaha dari masyarakat Desa Margorejo meliputi kegiatan peternakan, kegiatan pemanfaatan pekarangan, dan industri rumah tangga. Peternakan yang terdapat di Desa Margorejo yaitu meliputi Peternakan Kambing, Ayam, Bebek. Selain kegiatan peternakan di atas untuk meningkatkan sumber ekonomi keluarga juga melakukan pengelolaan pekarangan, antara lain penanaman pohon pisang, kakao/coklat dan warung. Umat Buddha di Kabupaten Pesawaran yang berjumlah 0,46 \% dari total penduduk provinsi Lampung sudah sewajarnya diperhatikan sehingga pola 
pemberdayaan yang dilaksanakan oleh pemerintah Desa mutlak dilaksanakan secara maksimal. Desa Margorejo saat ini terdiri dari 7 dusun dan 25 RT. Jarak desa dari kecamatan kurang lebih $10 \mathrm{Km}$. Total Jumlah penduduk desa Margorejo 4.016 jiwa dengan rincian, laki-laki sebanyak 2.103 jiwa dan perempuan 1.913 jiwa (Badan Pusat Statistik Kabupaten Pesawaran, Kecamatan Tegineneng dalam Angka (Tegineneng Subdistrictin Figures 2017).

Desa sebagai organisasi pemerintahan yang paling dekat dan berhubungan langsung dengan masyarakat merupakan ujung tombak keberhasilan pembangunan kota khususnya otonomi daerah, dimana Desa akan terlibat langsung dalam perencanaan dan pengendalian pembangunan serta pelayanan. Sebagai ujung tombak karena Desa berhadapan langsung dengan masyarakat, oleh karena itu Desa harus mampu menjadi tempat bagi masyarakat untuk diselesaikan atau meneruskan aspirasi dan keinginan tersebut kepada pihak yang berkompeten untuk ditindak lanjuti. Disamping itu peran Desa di atas menjembatani program-program pemerintah untuk disosialisasikan kepada masyarakat sehingga dapat dipahami dan didukung oleh masyarakat.

\section{Tinjauan Pustaka}

Pemberian pelayanan yang baik merupakan salah satu upaya perusahaan untuk menciptakan kepuasan bagi konsumennya. Jika konsumen merasa telah mendapatkan pelayanan yang baik berarti perusahaan mampu memberikan pelayanan yang baik pula. Demekian pula sebaliknya, pelayanan tidak dapat diuraikan secara obyektif seperti sebuah produk, melainkan merupakan interaksi 
sosial dengan subyektivitas, lebih tergantung pada nilai, parasaan dan perilaku.

Goetsch dan Davis yang diterjemahkan Fandy Tjiptono (2000: 101) membuat definisi mengenai kualitas sebagai berikut: "Kualitas merupakan suatu kondisi dinamis yang berhubungan dengan produk, jasa, manusia, proses, dan lingkungan yang memenuhi atau melebihi harapan" Definisi kualitas di atas mengandung makna bahwa elemen-elemen kualitas yaitu:

a. Kualitas merupakan kondisi yang dinamis

b. Kualitas berhubungan dengan produk jasa, manusia, proses dan lingkungan.

c. Kualitas meliputi usaha memenuhi atau melebihi harapan pelanggan.

Menurut Wyckcof dan Lovelock dalam bukunya yang dikutip dan diterjemahkan oleh Fandy Tjiptono (2000: 60) ada dua faktor utama yang mempengaruhi kualitas pelayanan yaitu respected service dan perceived service. Apabila jasa yang diterima atau dirasakan (perceived service) sesuai dengan yang diharapkan, maka kualitas jasa dipersepsikan sebagai kualitas ideal. Sebaliknya jika jasa yang diterima lebih rendah daripada yang diharapkan, maka kualitas jasa yang dipersepsikan buruk. Baik tidaknya kualitas jasa tergantung pada kemempuan penyedia jasa dalam memenuhi harapan pelanggannya secara konsisten.

\section{Pelayanan Hukum dan Administrasi Kependudukan di Desa}

Pemerintah berkewajiban dan bertanggung jawab untuk memberikan pelayanan dengan baik dan profesional, pelayanan publik (public services) oleh 
birokrasi publik merupakan salah satu perwujudan dari fungsi aparatur negara sebagai abdi masyarakat di samping sebagai abdi negara, dalam rangka menciptakan kesejahteraan pada masyarakat. Pelayanan publik merupakan titik strategis dalam pengembangan good governance. Salah satu dari tugas-tugas pemerintah yaitu pelayanan pembuatan kartu tanda penduduk (KTP) dan dalam pelaksanaannya berkaitan erat dengan hak bagi setiap warga Negara Indonesia. Sebagaimana yang dikatakan oleh Masrin (2013:68) salah satu dari tugas-tugas umum pemerintahan adalah sistem administrasi kependudukan, yang dalam pelaksanaannya berkaitan erat dengan hak sipil atau hak perdata penduduk.

Pembuatan e-KTP merupakan salah satu wujud pelayanan dasar pemerintah kepada masyarakatnya. E-KTP merupakan unsur penting dalam administrasi kependudukan. Alasannya adalah karena e-KTP menyangkut masalah legitimasi seseorang dalam eksistensinya sebagai penduduk dalam suatu wilayah Negara Kesatuan Republik Indonesia ( NKRI ) dan sesuai dengan UU Nomor 24 Tahun 2013 pasal 63 ayat 1 yang berbunyi penduduk WNI dan orang asing yang memiliki izin tinggal tetap dan sudah berumur 17 (tujuh belas) tahun atau telah menikah atau pernah menikah wajib memiliki KTP elektronik.

Sanksi yang diberikan oleh pemerintah terhadap masyarakat yang tidak membuat e-KTP adalah berupa sanksi administrasi. Sanksi administrasi dalam bentuk penonaktifan KTP ini akan membuat penduduk atau masyarakat tidak mendapatkan pelayanan publik. Contohnya dalam pembuatan BPJS yang basisnya adalah NIK, jika dalam pembuatan BPJS Nomor Induk Kependudukan tersebut tidak muncul maka hak dia sebagai penduduk 
Indonesia tidak akan bisa dipenuhi. Selain itu contoh dari pelayanan publik lainya yang tidak bisa didapatkan bila tidak membuat e-KTP adalah layanan kepolisian, layanan kesehatan, layanan izin mendirikan bangunan dan sebagainya.

Pelayanan dalam pembuatan e-KTP pada berbagai daerah di Indonesia memiliki tingkat kualitas yang berbeda-beda. Salah satu contohnya bahwa capaian target perekaman data yang masih belum terpenuhi sesuai dengan target waktu yang ditentukan. Begitu juga dalam hal koordinasi antar bagian dan unsur dalam proses perekaman data juga masih belum berjalan dengan baik. Di samping itu motivasi masyarakat untuk hadir dalam perekaman data juga masih rendah, terutama pada warga masyarakat di daerah pedesaan.

Belum tercapainya target pelaksanaan ini menggambarkan bahwa efektivitas kegiatan masih belum tercapai maksimal dan tentu saja secara anggaran biaya menjadi tidak efisien. Berdasarkan kependudukan didesa margorejo, jumlah penduduk mencapai 4.061 jiwa, dengan rincian, laki-laki sebanyak 2.103 jiwa dan perempuan 1.913 jiwa, dilakukan perekaman e-ktp dengan melibatkan warga masyarakat dan umat Buddha. Dalam hal ini pemerintah desa berinisiatif untuk mendata semua warga masyarakat melalui Kepala dusun dan Ketua RT setempat.

\section{Pelayanan menurut Ajaran Buddha}

Pelayanan dalam agama dapat berkembang, melalui pelayanan yang baik dari penyuluh agama. Pelayanan keagamaan yang dilakukan oleh penyuluh agama secara berkala akan membuat umat lebih mengerti mengenai ajaran agama Buddha. penyuluh harus bisa menyesuaikan dengan kebutuhan dan kondisi umat. Idealnya setiap daerah yang memiliki jumlah umat Buddha banyak atau sedikit 
membutuhkan tenaga-tenaga penyuluh yang terampil, profesional dan memadai. Ketersediaan tenaga penyuluh yang memadai diharapkan mampu membawa pengaruh baik terhadap perkembangan agama Buddha di berbagai daerah. Keberadaan peyuluh sangat dibutuhkan oleh masyarakat, jika pelayanan dari para penyuluh maksimal maka umat Buddha akan terus berkembang. Namun pada kenyataannya masih sangat kurang tenaga penyuluh membuat jumlah umat Buddha semakin berkurang. Penurunan jumlah umat Buddha terjadi karena kurangnya pembinaan dari penyuluh agama. Untuk itu pembinaan kepada umat harus intensif dilaksanakan terutama pembinaan kepada umat dipelosok daerah.

Berdasarkan hal di atas, berbagai upaya untuk memaksimalkan peran penyuluh agama harus dilakukan. Bentuk pelayanan yang dilakukan oleh penyuluh harus lebih inovatif. Hal tersebut dapat dimulai dengan menyediakan tenaga penyuluh yang berkompeten. Umat wajib mengikuti setiap kegiatan yang dilaksanakan dan ikut serta menyukseskan kegiatan tersebut. Hal ini dapat membantu pelaksanaan peran penyuluh secara maksimal. Penyuluh agama Buddha adalah umat Budha yang memberikan bantuan dalam hal ini memberikaan penyuluhan secara terus menerus agar orang tersebut tumbuh pribadi yang baik. Warsana (2008: 4) menjelaskan bahwa penyuluhan agama Buddha merupakan suatu bentuk kegiatan komunikasi yang bertujuan untuk membangun masyarakat dan bangsa melalui pendekatan agama Buddha. Melalui pendekatan Buddha diharapkan umat dapat mengerti tentang ajaran Buddha dengan benar. 
(Priastana 2005: 18) menjelaskan tujuan penyuluhan dalam agama Buddha adalah meningkatkan keyakinan (saddha) dan bakti umat Buddha di dalam berbagai bidang masyarakat. Dengan memahami ajaran Buddha dengan benar maka umat Buddha akan bertambah keyakinan sehingga dapat mempraktikkan ajaran Buddha dengan benar. Selanjutnya Supartini, dkk (2007: 12) menjelaskan dalam bidang pelayanan penyuluh memiliki peran yang sangat besar, mengingat tugas dan fungsi penyuluh adalah melayani masyarakat maka dijelaskan praktik pelayanan agama yang diberikan untuk umat Buddha. Karena perannya yang penting maka penyuluh selain memberikan pelayanan yang baik dan bersikap profesional.

Berdasarkan Surat Keputusan Bersama Mentri Agama RI dan Kepala Badan Kepegawaian Negara Nomor 574 Tahun 1999 Dan Nomor 178 Tahun 1999, melekat didalamnya trilogi fungsi penyuluh yaitu (1) fungsi informatif dan edukatif, (2) fungsi konsulatif, (3) fungsi advokatif, fungsi administratif (agus Mulyono, 2014)

\section{Metode Penelitian}

Penelitian ini adalah penelitian kualitatif dengan pendekatan yuridis dan sosiologis serta berusaha menguraikan masalah "Pandangan Umat Buddha Terhadap Hukum dan Administrasi Kependudukan di Desa Margorejo, Tegineneng, Kabupaten Pesawaran, Lampung”. Penelitian ini dilakukan di Desa Margoejo, Kecamatan Tegineneng, Pesawaran, Lampung sebagai objek penelitiannya. 


\section{Hasil Penelitian dan Pembahasan}

Bentuk pelayanan hukum dan administrasi kependudukan dilakukan di masyarakat desa margorejo. Pelayanan dibidang hukum dilakukan terutama jika terjadi masalah-masalah yang berhubungan dengan masalah kriminal seperti ada pencurian, kerusuhan dan lain sebagainya, sedangkan bentuk pelayanan administrasi kependudukan dilakukan melalui pelayanan dalam pembuatan kartu tanda penduduk (KTP), pelayanan Kartu Keluarga (KK), pembuatan akte kelahiran dan surat-surat lain yang berhubungan dengan hak-hak dari warga.

Berkaitan dengan hal tersebut perlu dilakukan penyelidikan atau penelitian yang dapat memberikan penjelasan mengenai Implementasi dalam pelayanan Hukum dan Administrasi Kependudukan bagi umat Buddha.

Berdasarkan wawancara penulis dengan tokoh umat Buddha (Bapak Jumiran) menujukkan bahwa implemtasi pelayanan hukum dilakukan dengan baik. Ini terbukti dalam penanganan masalah hukum dan kriminal seperti adanya pencurian dan kerusuhan dapat ditangani dengan menyediakan satuan pengamanan (Brimob). Penempatan polisi desa memberikan rasa nyaman bagi masyarakat untuk mengantisipasi masalah-masalah yang mungkin timbul, sedangkan mengenai pelayanan administrasi kependudukan dilakukan oleh Kepala Desa yang dilaksanakan oleh sekretaris desa dengan mengkoordinir kepala dusun dan RT dalam proses pengurusan KTP, KK dan Akte Kelahiran. 
Berdasarkan hasil wawancara dengan bapak Sujarwo implementasi pelayanan hukum dan administrasi kependudukan dilakukan dengan baik. Jika ada umat Buddha yang ingin mengurus masalah administrasi kependudukan, ketua vihara menginformasikan dan mengkoordinir kepada umat Buddha supaya mengurus dan menyiapkan berkas yang diperlukan. Jika ada kegiatan berhubungan dengan kegiatan keagamaan di luar desa maka ketua vihara melakukan pemberitahuan kepada kepala desa. Bentuk pelayanan yang lain adalah menjembatani kegiatan vihara dan tugas-tugas dari pemerintah desa, misalnya pada perayaan waisak pengurus dari umat Buddha mengajukan surat pemberitahuan kepada kepala desa untuk menjaga keamanan vihara. Kepala Desa menindaklanjuti dengan menerjunkan aparat keamanan, dalam hal ini polisi untuk menjaga selama perayaan waisak berlangsung.

Berdasarkan hasil wawancara dengan bapak Parjito Bentuk pelayanan hukum dan administrasi kependudukan dilakukan dengan melakukan kegiatan perbaikan jalan secara gotong royong, melakukan pemasangan lampu jalan di desa, melakukan pemberitahuan tertulis tentang pelaksanaan upacara kemerdekaan setiap tanggal 17 agustus, dan melakukan anjangsana dalam rangka peringatan hari raya waisak. Berkaitan dengan pelayanan adiministrasi kependudukan pihak kelurahan menginformasikan dan mengkoordinir secara lisan melalui kepala dusun dan ketua RT dalam pembuatan KTP secara masal. Kegiatan lain yang dilakukan oleh pemerintah desa adalah menfasilitasi program kabupaten yakni program bedah rumah bagi masyarakat yang kurang mampu. 
Dalam proses pelayanan hukum dan administrasi kependudukan pihak pemerintahan desa terkadang menemui hambatan. Hambatan ini terjadi karena berbagai hal seperti komunikasi yang kurang intensif antara pemerintah desa dengan umat Buddha dan warga.

Berdasarkan hasil wawancara dengan bapak Parjito hambatan yang pernah terjadi adalah sulitnya pengumpulan berkas dikarenakan kurangnya respon dari umat Buddha dan warga sehingga pemerintah desa terjun langsung ke masyarakat. Setiap ada keluhan dari warga pemerintah desa tidak langsung merespon dan menindaklanjuti, seperti pengurusan KTP yang terlalu lama. Masalah lain yang muncul adalah terjadinya penyaluran bantuan sosial yang tidak merata, terutama kepada yang lanjut usia, jalan yang rusak yang tidak kunjung diperbaiki serta pembangunan jalan yang tidak merata (kurang lebih $200 \mathrm{~m}$ di depan vihara tidak diaspal tanpa penjelasan ke warga)

Berdasarkan hasil wawancara dengan bapak Jumiran hambatan yang pernah terjadi adalah umat Buddha kurang peduli dalam kewajibannya mengurus berkas administrasi kependudukan, seperti KTP yang sudah habis masa berlakunya (sebelum muncul program E-KTP) tidak diurus jika tidak diberitahu. Wawancara dengan Bapak Sujarwo selaku Ketua Vihara menunjukkan bahwa hambatan yang terjadi adalah warga masyarakat dan umat Buddha sikapnya hanya menunggu, sebelum ada informasi dari sekretaris desa yang dikoordinir melalui kepala dusun dan ketua RT. Masalah lain yang muncul jika mengurus pembuatan KTP, blanko 
KTP sering kosong dan dalam proses pendaftaran KTP selesai terlalu lama kurang lebih 5 bulan. Upaya pemerintah desa mengatasinya dengan memberikan surat keterangan kependudukan sementara.

\section{Kesimpulan}

1. Pelayanan Hukum dan Administrasi Kependudukan bagi umat Buddha yang dilakukan oleh pemerintah desa adalah berkaitan dengan masalah hukum seperti terjadi pencurian dan kerusuhan dan masalah administrasi kependudukan berkaitan dengan pengurusan Kartu Tanda Penduduk, Kartu Keluarga dan lain sebagainya.

2. Implementasi dalam pelayanan Hukum bagi umat Buddha adalah melaksanakan penanganan tindakan kriminal seperti adanya pencurian dan kerusuhan. Masalah ini dapat ditangani dengan menyediakan satu orang brimob (polisi), sehingga masalah-masalah dapat segera diatasi. Kegiatan lain yang dilakukan adalah melakukan perbaikan jalan secara gotong royong, melakukan pemasangan lampu jalan, pelaksanaan upacara kemerdekaan setiap tanggal 17 agustus, dan melakukan anjangsana kepada umat Buddha dalam rangka peringatan Hari Raya Waisak. Implementasi Administrasi Kependudukan bagi umat Buddha adalah pengurusan Kartu Tanda Penduduk (KTP), Kartu Keluarga dan Akte Kelahiran.

3. Hambatan yang muncul dalam pelayanan hukum dan proses administrasi Kependudukan bagi umat Buddha di masyarakat adalah kurangnya kepedulian mengenai kewajiban sebagai warga masyarakat dalam pengurusan KTP, KK dan Akte Kelahiran, Penyaluran bantuan sosial yang tidak merata terutama 
kepada kaum lanjut usia, jalan yang rusak yang tidak kunjung diperbaiki, pembangunan jalan yang tidak merata sehingga tanpa penjelasan ke warga masyarakat.

\section{B. Saran}

1. Memberikan sumbangan pemikiran terhadap umat Buddha di desa margorejo mengenai pentingnya kewajiban sebagai warga negara berkaitan dengan masalah hukum dan admnistrasi kependudukan.

2. Pihak pemerintah desa memaksimalkan peran dalam pelayanan hukum dan administrasi kependudukan terutama perlu melakukan sosialisasi kepada warga masyarakat.

3. Umat Buddha perlu berperan aktif dalam mengikuti program pelayanan hukum dan administrasi kependudukan sehingga hasilnya akan meningkat.

\section{DAFTAR PUSTAKA}

Agus Dwiyanto, 2006. Mewujudkan Good Geovernance Melalui Pelayanan Public. Yogyakarta. UGM Press.

Agus Mulyono. 2014. Pemberdayaan Penyuluh Agama Dalam Peningkatan Aksara.

Asep Djadja Saefullah. 1992. "The Impact of Population Mobility on Two Village Australia : Adelaide. www.akademika.or.id,arsip,EC-POP1 Communities of West Java, Indonesia”. The Flinders University of South

Danim, Sudarwan. 2002. Menjadi Peneliti Kualitatif. Bandung. Pustaka Setia.

Eny Kusdarini, 2011. Dasar-Dasar Hukum Administrasi Negara. Yogyakarta. UNY Press.

Fandy, Tjiptono, 2000 .Manajemen Jasa, Yogyakarta . Andy.

Hardiyansyah, 2011.Kualitas Pelayanan Publik. Yogyakarta.Gaya Media. 
Inu Kencana Syafiie. 1999. Ilmu Administrasi Publik. Jakarta. PT. Rineka Cipta.

Jo Priastana. 2005. Komunikasi dan Dharmaduta. Jakarta: Yayasan Yasodara Puteri.

Kamus Besar Bahasa Indonesia, 2008. Jakarta. Balai Pustaka. Kinerja Instansi Pemerintah. Jakarta.

Lembaga Administrasi Negara. 1999. Pedoman Penyusunan Akuntabilitas

Moenir. 2002. Maanajemen Pelayanan Umum di Indonesia. Jakarta. PT. Bumi Aksara.

Ratminto \& Atik Septi Winarsih. 2006. Manajemen Pelayanan. Solo. PustakaPelajar.Republik Indonesia.

Sinambela, Lijan Poltak. Dkk. 2011 .Reformasi Pelayanan Publik. Jakarta.Bumi

Sugiyono. 2007. Metode Penelitian Kuantitatif Kualitatif dan $R \quad \& \quad D$. Bandung.Alfabeta.

Supartini, dkk.. 2007. Pola Pembinaan Lembaga Keagamaan Buddha. Jakarta.

Warsana. 2009. Petunjuk Pelaksanaan Penyuluh Agama Buddha. Jakarta.Direktorat Jendral Bimbingan Masyarakat Buddha Departemen Agama 